ancient Greek shorthand readable under magnification. He further claimed that

this 'finding' proved the authorship of Bacon, who he claimed had invented a microscope centuries before Antonie van Leeuwenhoek. After Newbold's death, the 'shorthand' was revealed to be random cracks left by drying ink.

Wisely, little space is devoted to the many speculative theories of origin and meaning. The manuscript has been cast, for instance, as a Middle High German hygiene manual written in 'mirror writing' - the technique used by Leonardo da Vinci - and as a herbal manuscript in the Aztec language Nahuatl. (Readers with a taste for these can consult The Voynich Manuscript (Orion, 2004), a study by Gerry Kennedy and Rob Churchill.) And no new decipherment is offered.

Some idea of the complexity of the story is shown by a letter in Latin that Voynich apparently found affixed to the manuscript. This is reproduced in the volume, oddly without translation. Dated 1665, it was written by Johannes Marcus Marci (physician to the Holy Roman Emperors) and addressed to his former tutor, the Jesuit Athanasius Kircher. (The foremost polymath of the age, Kircher was wrongly credited with deciphering Egyptian hieroglyphs.) In the letter, Marci notes that he is sending Kircher the entire manuscript, asks him to decode it and mentions the claim that Bacon authored it. We know that Kircher received the manuscript, but made no progress with it. After his death in 1680, it disappeared into Jesuit archives in Rome until it came into Voynich's hands.

What hope is there of decoding the script? Not much at present, I fear. The Voynich manuscript reminds me of another uncracked script, on the Phaistos disc from Minoan Crete, discovered in 1908. The manuscript offers much more text to analyse than does the disc, but in each case there is only one sample to work with, and no reliable clue as to the underlying language - no equivalent of the Rosetta Stone (A. Robinson Nature 483, 27-28; 2012). Professional cryptographers have been rightly wary of the Voynich manuscript ever since the disastrous selfdelusion of Newbold. But inevitably, many sleuths will continue to attack the problem from various angles, aided by this excellent facsimile. Wide margins are deliberately provided for readers' notes on their own ideas. "Bonne chance!" writes Clemens. I'll second that.

Andrew Robinson's many books include The Man Who Deciphered Linear B and Lost Languages.

e-mail:andrew@andrew-robinson.org

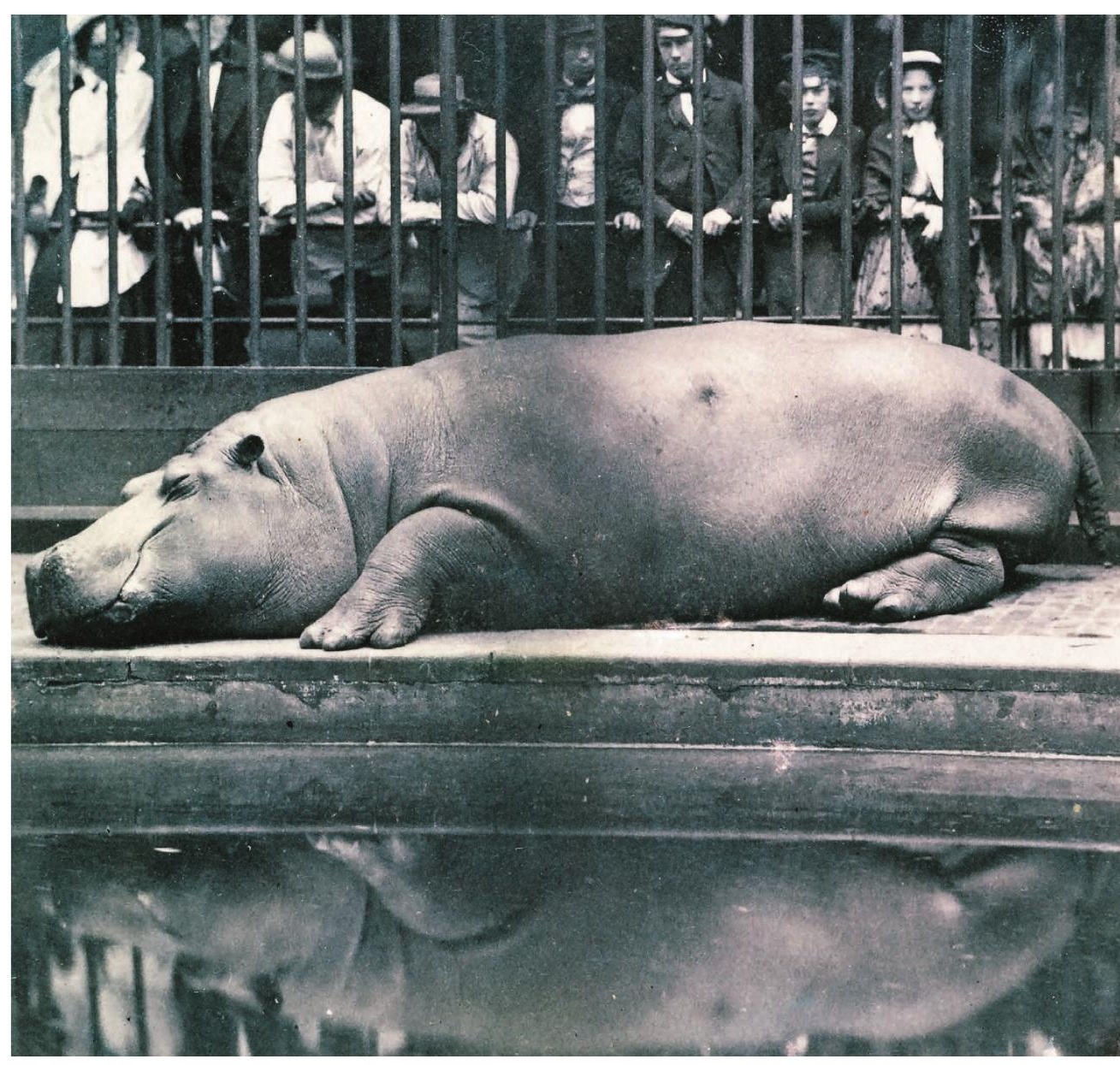

Obaysch the hippo was captured in 1849 and sent to London Zoo, where he became a sensation.

ZOOLOGY

\title{
Animal crackers
}

\section{Henry Nicholls relishes a brace of chronicles on how zoos on both sides of the Atlantic came to be.}

S tamford Raffles did not waste his time. In 1825 , little more than six months after returning to London from the East Indies, he'd put together a prospectus that would result in the creation of the Zoological Society of London (ZSL). With his career as an entrepreneur-cum-statesman in Penang, Java, Sumatra and Singapore behind him, Raffles was ready to indulge his passion for natural history.

The relationship between humans and the rest of the animal kingdom has always changed and will always change. But there can be few shifts as rapid and radical as those in the nineteenth century. With the age of sail in full swing and European docksides piled with boxes of specimens, a new class of professional zoologist arose. The likes of Alexander von Humboldt, Charles Darwin and Alfred Russel Wallace began to make sense of the
The Zoo: The Wild and Wonderful Tale of the Founding of London Zoo

ISOBEL CHARMAN

Viking: 2016.

The Animal Game: Searching for Wildness at the American Zoo

DANIEL E. BENDER

Harvard University Press: 2016.

astounding variety of animal life. The period covered in Isobel Charman's The Zoo, 182451 , saw much of the transformative action. Meanwhile, historian Daniel Bender's The Animal Game chronicles the evolution of the US zoo from the 1870s to the 1970s.

Charman has hit on a delightful structure for her "wild and wonderful tale". Each chapter is a leg in a relay. So Raffles hands over to Decimus Burton, the ambitious twentysomething architect who began to shape 
the zoological gardens in Regent's Park in 1827. Veterinary surgeon Charles Spooner is next, his struggle to keep the animals alive in the 1830 s foreshadowing concerns over animal welfare. On the upside, the deceased creatures were a bonus for chief animal preserver John Gould and the ZSL's museum in Mayfair, a collection subsumed into the British Museum in 1855. Gould pops up again later with a selection of Galapagos finches, which helped Darwin to develop the case for evolution by natural selection. Thus Charman takes the story out of the cages and onto the smoggy, sometimes riotous streets of Victorian London, up and down the country and beyond its shores.

With an imperial network of travellers and traders, customs officials and collectors, dealers and diplomats all sending specimens to London, the nascent zoo boasted an impressive diversity of animals from the off. During its first decades, the zoological gardens remained relatively exclusive, as its fellows mulled over the peculiar physiology, morphology and behaviour of inmates such as a chimpanzee that they named Tommy. The public, meanwhile, indulged their curiosity at venerable but unashamedly unscientific menageries such as the Exeter Exchange on London's the Strand. Soon, Raffles' original vision, emphasizing the animals as objects of scientific research, became hard to sustain. The ZSL gave up its farm outside Kingston upon Thames - a site for breeding and experiments - and opened the gates of the zoological gardens in the 1840s. It also began to bring in crowd-pleasers such as giraffes and hippopotamuses.

What is perhaps most striking about The Zoo is its style. "He could see it now, in his mind's eye," Charman writes as Raffles' plans take shape. "All of these beasts, from across the earth, from every corner of the endless Empire,

\section{"Urban elites who dreamed of zoological parles fantasized that displays of biological order would beget social order."}

gathered right here! He could almost hear the roars." It is clear that a huge amount of research has gone into this work, but much is lost among imagined thoughts and feelings. In writing non-fiction novelistically, Charman fails to take full advantage of the strengths of either genre.

Bender takes a more conservative approach in The Animal Game. Given the imperial premise of a robust zoological collection, it makes perfect sense that the appearance of US zoos should map onto the emergence of the nation as a global power towards the end of the nineteenth century. The Philadelphia Zoological Society the country's oldest - appeared in 1859, although it achieved a permanent collection

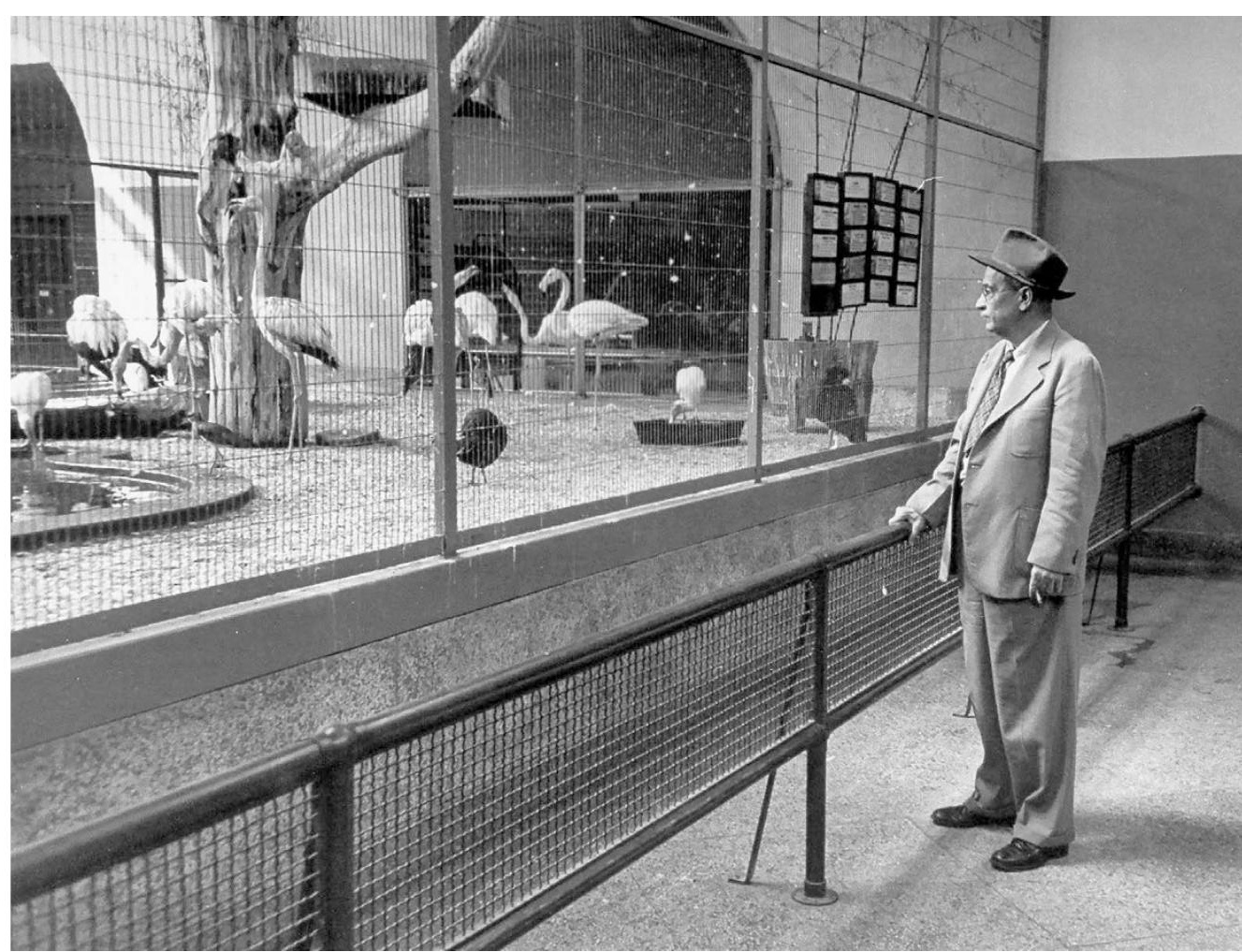

William Mann, fifth director of the National Zoo in Washington DC, travelled widely to collect animals.

(including an Asian elephant, Jennie) only some 15 years later. Others included Lincoln Park Zoo (Chicago, Illinois, in 1868), the National Zoo (Washington DC, 1889) and the Bronx Zoological Park in New York City (1899). In many ways, the stories of these institutions mirror the ZSL's. As with Raffles, "those urban elites who dreamed of zoological parks fantasized that displays of biological order would beget social order", writes Bender: nature's hierarchy offered a model to the masses. Also like the ZSL, US zoological societies struggled to distinguish themselves from low-brow entertainment menageries, circuses and world fairs.

Whereas the animal trade is implicit in The Zoo, Bender's book renders it explicit through characters such as Frank Buck animal dealer, showman and film star - and William Mann, the pith-helmeted director of the National Zoo from 1925 to 1956. In 1937, Mann travelled to the Far East to secure tigers (at US\$100 a pair), a Sumatran gibbon, cassowaries, orang-utans and more. In Africa, he had to manage his own collecting, on one occasion employing 500 locals in a failed attempt to net a giraffe. When he sailed for the United States, he had a cargo of 1,500 animals, but many were dying: a crate of 14 pythons was summarily thrown overboard. $\rightarrow$ NATURE.COM For more on science in culture see:

nature.com/ booksandarts
During the Great Depression, bankrolled by federal coffers, many zoos began to reconfigure with new displays such as "monkey islands" surrounded by moats. Captive breeding eventually appeared, as much by necessity as design: by the 1960s, centuries of exploitation had devastated wild animal populations. The only way that zoos could survive was to put more effort into breeding their own animals.

Bender zips back and forth from institution to institution, on collecting trips with traders, and with visitors feeding the animals snacks (and on occasion, broken bottles and roofing nails). He draws on rich archival material, including the thoughts of key players such as zoologist William Temple Hornaday, memos from management and a flurry of clippings from the popular press. In the century that he covers, US zoos faced challenges from economic ups and downs to rogue animals, disgruntled staff and a demanding public.

What emerges is a story of adaptation and survival that exposes the modern zoo as "a third nature", a "product of how we built, lived, and contested empires. It is wildness and wilderness suspended at the moment of their initial enclosure when there were still plenty of animals for the taking." Those who are ethically opposed to zoos will find plenty here to strengthen their case. But with zoos' power of reinvention, it seems likely that this "third nature" will be with us for some time.

Henry Nicholls is a journalist based in London. His latest book is The Galapagos. e-mail:henry@henrynicholls.com 